\title{
Female Enterpreneur of Small Businesses Challenges in Kosovo
}

\author{
Bekim Syla \\ “Gold Training Center”, Ferizaj \\ Dr. Sc. Veli Lecaj \\ Public University "Ukshin Hoti”, Faculty of Economics, Prizren
}

Doi:10.5901/ajis.2015.v4n2p561

\section{Abstract}

Nowadays it is more than obvious that women as entrepreneurs are moving forward in advancing the role in the process of improving the quality of work and increasing business results, powered with comparative and competitive vigilance. First of all in terms of female position in Kosovo' society, and secondly, in their ability to absorb the challenges of business environment, participation in the market, and the possibility of more efficient business. Based on these facts the promoting of female as owner of small business that historically had only ceremonial role but needs of the involvement of female skills and evolve its position encouraged all shareholders to ensure quality business, products or services with high quality and valued clients, which it achieved through a genuine commitment of women from inner and outer of the company, adding at the same time care instinct from female perspectives to their clients, managing current market share and enlargement of it in the market share. To achieve this, women entrepreneurs must be aware on how to do deal with challenges, they must be ensured to stay all the time motivated, working consistently and with enthusiasm for a qualitative change. Keeping in mind the role of women in SE (Small Enterprises) is an important generator of economic development of a certain country and especially in Kosovo as a country in transition. But the challenges of women in the organizations of SE in Kosovo are many, divulged from ranging from the most basic definition of the market share, unfair competition based on ignorance of the female, informal economy up to financial abilities to create a steady operating environment. As one of the most important challenges for women entrepreneurs is without doubt the ability to manage a business and care for the family evolved and Kosovar women are more career oriented in an harsh and dynamic environment, challenged to follow competitors with innovations and high-tech manufacturing products as well as communication, reducing entry barriers in some markets as a result of electronic business, the demand to respond quickly to customer needs, which requires not only supplement of functional and emotional needs, but also their spiritual supplement to the mind, spirit and heart. Kosovar women today tend to manage small capital companies, production industry and services makes the possibility still challenging and perspectives of their development due to informal economy, unfair competition and the impact of economic development entity of Kosovo.

Keywords: Small Enterprise, Females in SE, shareholders, Organizational ability, and success factors, female participation, financing, competition, market, informal economy.

\section{Introduction}

The private initiative of new entry businesses has increasingly taken place in post-war Kosovo, the SE have a very important role in the socio-economic creation of new jobs in situated of high unemployment rate.

SE's foundation and raising the level of entrepreneurial ability provides employment opportunities, which can help to reduce unemployment, in facing demographic challenges, increased social welfare, alleviating gender inequalities, reducing youth problems especially Kosovar youth which is growing fast. On the other hand the development of the SE sector can contribute to strengthening the competitiveness between businesses from both genders and possible managerial and structural change. Such evolution of business promotes structural and technological transformation towards innovative approaches and their application in business either by men or women entrepreneurs. The women are engaged slowly but steadily in the business, as they initially are facing major difficulties, ranging from prejudice for their leadership skills, inexperienced in business, mentality of society which has made an impact very negative to businesswomen, so the access to funding sources, etc.

But over the years, especially over the last decade, there has been a greater impetus to their access to education, as the key point, and consequently their participation in women owned enterprises of Kosovo are engaged in a steady change toward their position in society. Despite many difficulties, they are being well received by business activities, but 
to a quite low degree compared to men (www.albinfo.ch/femrat-ne-kosove-ngadale-por-sigurt-ne-biznes/S1iF5c7V.dpuf). It is worth mentioning that female entrepreneurs are essential for economic development of Kosovo which must be included in all spheres of society - government and private sector and which will contribute to the overall improvement of whether economic or social situation in urban and rural areas. There are major differences in terms of business ownership by gender. Statistical data show that only $6 \%$ of businesses in 2010 were owned by women, which is growing but not to desired level, to near $13 \%$ in 2014 , women owned businesses showing low level of activity of women entrepreneurs. (Oberholzner, 2014)

Registration, structure, concept of businesses and employment in Kosovo.

Table 1. Registered Enterprises in Kosovo according to the number of employers - 2010

\begin{tabular}{|c|c|c|c|}
\hline Company size & No. of emp. at business reg. & No. of Companies & Percent in total \% \\
\hline Micro & $1-9$ & 102,070 & $98.37 \%$ \\
\hline Small & $10-49$ & 1,406 & $1.35 \%$ \\
\hline Medium & $50--249$ & 221 & $0.22 \%$ \\
\hline Large & 250 tand more. & 58 & $0.06 \%$ \\
\hline Total & & 103,755 & $100.00 \%$ \\
\hline
\end{tabular}

Source: Kosovo business registration Agency/Ministry of Trade and Industry, Kosovo

Data from KBRA MTI, the number of private and public enterprises registered until December 31/2010 was 103,755, which employ 216,799 employers, or 62.24\% of the total employed in Kosovo. (Kosovo Statistical Agency, 2010)

Table 2. Registered Enterprises in Kosovo according to the number of employers - 2012 (Repertori statistikor mbi ndërmarrjet, 2012)

\begin{tabular}{|c|c|c|c|}
\hline \multicolumn{5}{|c|}{} \\
\hline Company size & Nr. of Companies & Nr. of Employees & $\%$ \\
\hline Micro & 109,800 & 185,129 & $64.30 \%$ \\
\hline Small & 1,508 & 24,877 & $8.60 \%$ \\
\hline Medium & 224 & 22,411 & $7.80 \%$ \\
\hline Large & 58 & 55,658 & $19.30 \%$ \\
\hline TOTAL & 111,590 & 288,075 & $100.00 \%$ \\
\hline \multicolumn{4}{|l}{} \\
\hline
\end{tabular}

Source: Kosovo business registration Agency/Ministry of Trade and Industry, Kosovo

Table 3. Registered Enterprises in Kosovo according to the number of employers 2010-2012

\begin{tabular}{|c|c|c|c|}
\hline \multicolumn{5}{|c|}{} \\
\hline Company Type & Nr. of Companies (2010 to 2012) & $\%$ & Nr. of Employees \\
\hline Micro & 7,730 & $98.66 \%$ & 70,321 \\
\hline Small & 102 & $1.30 \%$ & 928 \\
\hline Medium & 3 & $0.04 \%$ & 27 \\
\hline Large & 0 & $0.00 \%$ & - \\
\hline TOTAL & 7,835 & $100.00 \%$ & 71,276 \\
\hline
\end{tabular}

Data show that only during two years were registered 7835 new businesses among which micro businesses lead with 98.70\%, followed with $1.30 \%$ small businesses then have 3 medium new businesses registered or $0.04 \%$ and no Large type of business registered. Also during this period should be noted that from the above data continually in $2010-2012$ increasingly added 70276, the number of employers showing a slightly decrease of the unemployment rate in Kosovo (Lecaj, 2015)

The term small enterprises, exempting those businesses with fewer than 10 employees, which today represent 
$90 \%$ of all enterprises and employing $1 / 6$ of the entire workforce.

Kosovar women SE seek as the possibility as financing source and the chance to make a fortune. It is the place where creative and motivated women can fully use their talents and experience. It is the place where women aiming job opportunities and satisfying career. Every large successful start, starts as a small business. Women in SE are often very innovative owned company. They can launch new products, new styles and new promotional strategies. They provide a way for people to be "god" of their property.

The ability of women entrepreneurs happens when she develops a new enterprise, a new way of conducting business or developing old idea, adds the market a unique product or service, under conditions (terms) of the risk.

SE for women offers many existing opportunity. There is no question that small businesses will continue to play a vital role in advancing the position of women in society and in our economy. But to increase more chances for success, women are not overlooked by their inner instinct care to carefully analyse the advantages and disadvantages of SE. (J. Mariah Brown)

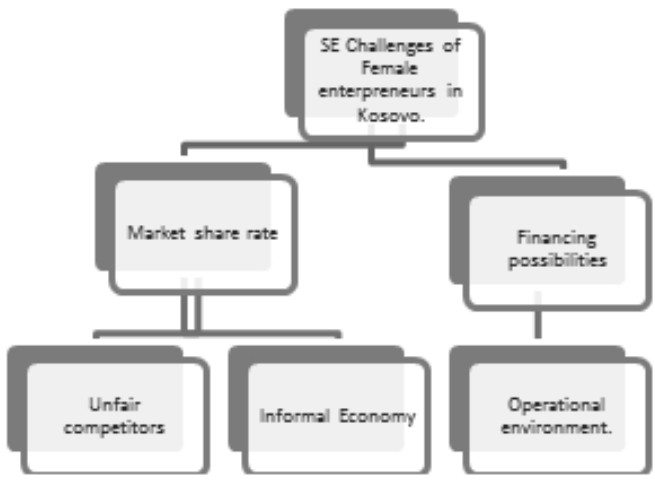

Figure 4. SE Female enterpreneur's challenges in Kosovo

SE challenges of the owned woman enterprises to develop more has to do with the aspect of competitive and financial ability, it now faces the broad gender issues of SE in Kosovo. The scope of the definition market share rate has shown a persistent impact of development strategies and Business perspectives from which enables the recognizing market and taking nutritional information of operational of SE, because of such recognition makes it easier access of products that are placed and prosperous prospect innovative aspect of $\mathrm{SE}$, but, according to this measurement barometers market share rate indicator is challenged by unfair competition and the informal economy which makes it difficult to develop propserues of women owned SE. With unfair competition we highlight the application of double standards for business entities based on their gender owned Enterprises that operate in Kosovo, including regional and local level, to the challenges of this type occur mainly based on the applied taxes that have businesses against such Tax administration Institutions as well as cases in which the same businesses face institutional reluctance support the competitive aspect of the business.

Although, proclaiming that the institutions that deal with the management of the involvement of women as entrepreneurs have created and continuously are creating a quiet operating environment, in fact, these institutions undertake measures taht affec competitive rights of women owned business entities of the same level, and the climate to operate is not deliberately supported same in all regions all around Kosovo, but that it varies depending on the region and even the location of the business entities.

Analyzing deeply the market share rate as the development challenge of SE, obviously needs to be addressed in terms of informal economy, according to barometers of "doing business" is not a small quote accepted publicly that the business performance of the informal Kosovo catch quota of $5 \%$ to the overall turnover, as for the quota of $5 \%$ would be acceptable, but we are in doubt that this quote is not real.

Today in Kosovo to register a new business you'll accomplish it in 15 minutes, and then the day later you are officially the owner of a business, but the question of operational and closing procedures, there are no data given by their agency management. (Doing business report, 2015)

According to data analyzed by the BSC SME Survey $2011,67 \%$ of owners have established their businesses 
based on their need to ensure basic existence, while only 33\% of owners stated that their businesses are established by analyzing and identifying good opportunity to develop the business. According to the respondents in this research it emerges that: $55.97 \%$ of the founders of enterprises have had great experience for businesses which have opened, or 23.69\% less experience and $20.34 \%$ started the business without any specific experience. (ibidem).

The SE challenge and perspectives of women owned enterprises of their development in Kosovo becomes even more un-affordable when added to the financing possibilities, was also mentioned above, participation and operational environment has created diverse barriers as the institutional as well as practical, so women owned enterprises in Kosovo faces a big question, whether to walk away, either with modifications and innovations or flounder in the way of its prosperous development.

New Women entrepreneurs have a uncertain journey due to the lack of funds flow in the market and the majority of the population so they are mainly orieneted at providing the most important products for them, thereby meeting consumers' needs not sustainable though, because their needs change towards their revenues, every day in Kosovo is decreasing more as a result of the fluctuation of money and their absorption ability within Kosovo, while on the other hand, subsidies do not meet the requirements of many of the entrepreneurs of SE in Kosovo .

\section{Conclusions}

Finally we can conclude that the central government in cooperation with the local government was facilitating the right steps for the registration of small business for women entrepreneurs but not for their facilitation of operation in the market by not offering them the necessary support to increase, which, as was seen in this work suffering from not having enough room to work, unfair competition, lack of support of their staff, subsidizing their products and so on. We should not forget that this kind of business has a significant number of employees and affects more than public sector leading to alleviation of unemployment.

From the analysis discussed in this paper noted that new entry women entrepreneurs mainly coming from their experience in large corporations and public sectors that use the created climate and circle of acquaintances and connections to advance their business.

We have tried to give answers that small business is not in a desired situation and their position is moving every day with unstable steps toward those women who will be encouraged to own a SE, as also mentioned by foreign and domestic institutions dealing in this field. Also various programs encourage women through the promotion and grants with more emphasize in female gender.

From this work we have learned how to diverse business and what are the criteria for a business to be characterized as a small business? We also have learned which institutions are dealing with the economic issues of this kind of business such as, KBRA, TAK, USAID, the American Chamber of Commerce, Kosovo Chamber of Commerce and other chambers, and what are the opportunities offered by these institutions to get information, or how to get the information from their reports and have access to information for female entrepreneurs. The most valuable contribution is providing World Bank report "Doing Business" that provides undisputed assistance for published information that were used to compile the analysis of this paper.

Special emphasis aspect has been paid of registration and changes that can be updated through KRBA, so it has been given the necessary space and the right to understand what is the steps to follow for women not to feel inferior in such cases.

\section{Recommendations}

It is recommended that the application for registration of women owner to be done electronically and to have access on information about the type of business to be updated by KBRA, which will further facilitate faster information and the rights of women owners of SE. It is recommended that TAK facilitates application and training of female owner for the applicable taxes on their activities.

It is recommended that the central institutions have on their agenda not only moral but also concrete support for women entrepreneurs in small businesses, and for all employees of these businesses to have exemptions encouraging women increasing the number of employees and registration of businesses by groups of people with disabilities, and women from minorities.

It is recommended that the Ministry of Finance not to allow Kosovo oligopoly markets which in this way will reduce the opportunities to enter the new owner business women. 
It is recommended on organizing a campaign to strengthen the role of women in the construction and development of stable enterprises. It should be organized and conduct training on the importance of strategic operational planning and women in economic activities for longer periods of time that would result in positive effects for the continuation of existing business, change of business and complete it with new activities, and expanding its business of fulfilment of new activities.

It is recommended to start with the application of incentive measures by the government for women owned enterprises which their main product is for export, such as the simplification of bureaucratic procedures, reducing customs tariffs, to organize campaigns in informing the women entrepreneurs with regional and international markets, signed agreements by the government of free movement of goods, improvement of road and railway infrastructure, incentives for women owned enterprises to enhance the quality of products of made in Kosovo. Attention should be paid to strengthen economic relations with other countries of the region, in order to create favourable conditions for women owning enterprises, to introduce and bring the local products in the regional markets and the European Union.

Women as owners of the enterprises in the Republic of Kosovo need to establish mitigation measures for foreign investors, including the simplification of administrative procedures of licensing of international companies that express interest to promote women as entrepreneurs in our country.

If the Government can't support it, at least needs to work closely with loaners that set the deadlines for repayment in order to be postponed, by applying more reasonable interest rates policies, also the assiduity should treat women equally in their financial analysis.

\section{References}

Lecaj, V. (2015),Product policy in economy of Kosovo,Pristina,p.114.

M. Mustafa, E. Kutllovci, P. Gashi, B. Krasniqi,(2006)Biznesi i vogël dhe i mesëm, Prishtinë, fq. 21-25, 29.

Lecaj, V. (2008) The role of promotion in stimulating of economical development of Kosovo, Prishtine, pp. 66-69.

http://smalllbusiness.chron.com/ advantages-disadvantages-business-ownership-20258.html

Rinvest,Prishtine , 2006,faqe,22-28

http://www.arbk.org/sq/Regjistrimi-i-biznesit

http://www.sme-ks.org/repository/docs/1-Koncepti_Zhvillimor_i_Agjencise.pdf

Anketimi i ndermmarjeve te vogla , RIINVEST, 2012

Banka Botërore, Treguesit e Zhvillimit Botëror 2012.

http://www.doingbusiness.org/ /media/giawb/doing\%20business/documents/profiles/country/KSV.pdf, p 16-23.

USAID, diagnozë e rritjes në Kosovë: Analizë e pengesave, shtator 2012.

USAID, Studim i efekteve nga furnizimi i parregullt me rrymë elektrike mbi bizneset kosovare, Nëntor 2012.

http://www.ebrd.com/downloads/country/strategy/kosovo-strategy-albanian.pdf, p 9-11

BSCK Study Research Report 2011

Barney, J. B. (1991). Firm resources and sustained competitive advantage. Journal of Management, 17, 99-120.

ACRONNYMS

KBRA- Kosovo Business Registration Agency.

MTI - Ministry of Trade and Industry. 
